Brit. F. vener. Dis. (1969), 45, 42.

\title{
SIMULTANEOUS ISOLATION OF Trichomonas vaginalis AND COLLECTION OF VAGINAL EXUDATE*
}

\author{
BY
}

\author{
D. H. H. ROBERTSON, W. H. R. LUMSDEN, K. F. FRASER, D. D. HOSIE, AND \\ D. M. MOORE \\ From the Department of Venereology, Edinburgh Royal Infirmary, and the \\ Department of Applied Protozoology Research, Centre for Tropical Veterinary Medicine, Royal (Dick) School of \\ Veterinary Studies, University of Edinburgh
}

For the purpose of immunological study of Trichomonas vaginalis infestation in man, methods were required for the simultaneous isolation of organisms and for the collection of material which might contain antibodies against the organisms. The present paper describes the method developed for females and relates it to the usual routine method for diagnosis of this infection, by microscopical examination of vaginal exudate.

\section{Subjects \\ Materials and Methods}

156 female patients attending the out-patient Venereal Diseases Clinic at the Royal Infirmary, Edinburgh, were examined. These included nineteen girls from approved schools, 25 pregnant women from a hostel for unmarried mothers, and 112 others. The ages of these patients varied from 13 to 56 years, except for one 3-week-old baby. All were patients attending for the first time, except that four were examined also a second time, making in all 160 applications of the procedure described below.

\section{Procedures}

(a) For microscopical examination of vaginal exudate. Material collected by cotton-wool applicator (Johnson \& Johnson (GB), Slough, England) from the posterior vaginal fornix was suspended in one drop of isotonic saline mixed with 1 per cent safranin in the proportion $5: 1$ on a slide, and covered with a cover slip. The film so prepared was examined by a clinician by transmitted light microscopy ( $\times 20$ objective, $\times 10$ eyepiece) within a few minutes of its preparation.

(b) For simultaneous isolation of organisms and collection of vaginal exudate.

(1) Pieces of polyester sponge (Campbell Brushes Limited, Cromwell Street, Dudley, England) $1 \times 1 \times 4$ $\mathrm{cm}$. were autoclaved individually in screw-capped Loewenstein bottles (Arnold Horwell, 2 Grangeway, Kilburn High Road, London, N.W.6). Using Hartman's

$\star$ Received for publication September 20, 1968. "crocodile" oral forceps (A. Young \& Son, Edinburgh, Scotland), a piece of the sponge was withdrawn from the bottle, used to soak up the fluid in the upper part of the vagina, and returned to the bottle, which was then closed for return to the laboratory.

(2) $1 \mathrm{ml}$. isotonic salts solution buffered (phosphate system) to pH 5.8 (Lumsden, Robertson, and McNeillage, 1966) was added to the bottle and mixed with the contents of the sponge by compressing the latter with a sterile wooden stick (Ashwood Timber Industries, Ibex House, Minories, London). The bottle was then attached to the "top" socket of a Hemmings filter (R. B. Turner, East Finchley, London, England) which was without filter pad and which carried a bijou bottle on the "lower" socket.

(3) The assemblies were then centrifuged at 900G for 10 minutes.

(4) The clear supernate was withdrawn by pipette and stored in $0.2 \mathrm{ml}$. quantities in $\mathrm{LP} / 2$ tubes (Shandon Scientific Company, Pound Lane, London, N.W.10) at $-20^{\circ} \mathrm{C}$.

(5) The deposit was resuspended in $0.5 \mathrm{ml}$. culture medium (Lumsden and others, 1966), and a wet film of the suspension was examined with $\times 10$ and $\times 40$ phase contrast objectives and $\times 10$ eyepiece.

(6) The residue of the suspension was inoculated, in approximately equal quantities, into two bijou bottles of culture medium and incubated at $37^{\circ} \mathrm{C}$ for 12 days.

(7) The cultures were examined for indicator colour change every 2 days and, if this occurred, its association with $T$. vaginalis was checked by microscopy as in (5) above. Cultures in which no colour change occurred were checked by microscopy in the same way before being discarded.

On all the 160 occasions on which the procedure was used, primary operations and examinations were completed in less than 60 minutes and on 137 ( 85 per cent) occasions in less than 30 minutes. Results recorded as microscopically positive imply the presence of motile $T$. vaginalis, in which flagella and/or undulating membrane could be seen. Results recorded as negative are on a basis of at least 10 minutes' examination. 


\section{Results}

The results are given in the Table.

TABLE

RESULTS OF DIRECT MICROSCOPY OF VAGINAL FLUID AND OF THE MICROSCOPICAL EXAMINATION AND CULTURE OF SAMPLES COLLECTED BY THE POLYESTER SPONGE METHOD

\begin{tabular}{|c|c|c|c|c|c|}
\hline \multirow{2}{*}{ Clinic } & \multirow{2}{*}{$\begin{array}{l}\text { Immediate } \\
\text { Microscopy of } \\
\text { Wet Film }\end{array}$} & \multicolumn{2}{|c|}{+} & \multicolumn{2}{|c|}{0} \\
\hline & & \multicolumn{2}{|c|}{44} & \multicolumn{2}{|c|}{116} \\
\hline \multirow{4}{*}{ Laboratory } & \multirow{2}{*}{$\begin{array}{l}\text { Microscopy of } \\
\text { Centrifuge } \\
\text { Deposit }\end{array}$} & + & 0 & + & 0 \\
\hline & & 33 & 11 & 5 & 111 \\
\hline & \multirow{2}{*}{$\begin{array}{l}\text { Culture of } \\
\text { Centrifuge } \\
\text { Deposit }\end{array}$} & +0 & +0 & +0 & +0 \\
\hline & & 303 & 110 & 50 & 4107 \\
\hline
\end{tabular}

The 116 occasions on which immediate microscopy of the wet film of the original exudate gave negative results may be considered first. Of these, five were found positive by microscopy of the deposit and in all these cases this was confirmed by culture. Of the remaining 111, still negative after both these microscopical examinations, four were found positive on culture. Thus, of the 116 designated as uninfected by the clinician's examination, nine ( 7.8 per cent) were recognized to be positive by the proposed method, which, therefore, is shown to be more sensitive.

Of the 44 cases in which infection was diagnosed by the clinician's microscopy of the wet film of the vaginal exudate, only 33 were confirmed by microscopy of the deposit. Thirty (91 per cent) of these were positive also on culture, which corresponds closely with the results of phase-contrast microscopy of the deposit. Of the eleven found negative by microscopy of the deposit, only one ( 9 per cent) was found positive by culture. It is likely, therefore, that most of these eleven patients were not in fact infected and that the 44 positives found by the clinician's examination contains a substantial proportion, perhaps over 20 per cent, of wrong diagnoses.

\section{Discussion}

As a diagnostic method, phase-contrast microscopy of the centrifuged deposit obtained by the procedure described is both more sensitive and more accurate than immediate transmitted light microscopy of a wet film of vaginal exudate as carried out under busy out-patient conditions by various clinicians. Improvement in the sensitivity of the clinician's microscopical examination is difficult, as the detection of low numbers of organisms may require prolonged search. Improvement in its accuracy should, however, be possible simply by limiting positive diagnosis to films in which the morphological features of flagella and/or undulating membrane of an organism are unmistakably recognizable.

The culture procedure now described is a more sensitive diagnostic method than microscopy. Whittington (1957) and Hoffman, Kilczewski, and Malyszkoe (1961) came to the same conclusion with their methods of culture. Immunological examination of the exudates obtained is in progress.

\section{Summary}

A method for the simultaneous isolation of Trichomonas vaginalis and for the collection of vaginal exudate for immunological study is described. The isolation techniques are shown to be both more sensitive and more accurate for diagnosis than immediate microscopy of wet films of vaginal exudate.

We wish to thank the clinicians at Ward 46, Edinburgh Royal Infirmary, particularly Dr. G. George and Dr. M. C. MacRae, for their constant help in this project.

\section{REFERENCES}

Hoffman, B., Kilczewski, W., and MALYSZKoE, E. (1961). Brit. F. vener. Dis., 37, 172.

LUMSDEN, W. H. R., ROBERTSON, D. H. H., and MCNEILlaGe, G. J. C. (1966). Ibid., 42, 145.

Whithington, M. J. (1957). Ibid., 33, 80.

\section{L'isolement du Trichomonas vaginalis et la prise simultanée de l'exsudat vaginal}

\section{RÉSUMÉ}

Une méthode pour l'isolement du Trichomonas vaginalis et la prise simultanée de l'exsudat vaginal pour les études immunologiques est décrite. Les techniques de l'isolement sont demontrées comme étant aussi bien plus sensible et plus exacte pour le diagnostic que la microscopie immédiate des films humides de l'exsudat vaginal. 